Research Square

\title{
Health and Ecological Risk Assessment of Exposure to Toxic Heavy Metals Found in Settled Dust in the City of Kerman, Southeast of Iran
}

\author{
Azam Rajabi \\ Kerman University of Medical Sciences \\ Aliakbar Roudbari \\ Shahrood University of Medical Sciences \\ majid aghasi ( $\nabla$ roodbari@shmu.ac.ir) \\ https://orcid.org/0000-0002-9672-3646
}

Research

Keywords: Biological monitoring, Heavy metals, Blood, Kerman

Posted Date: June 24th, 2020

DOI: https://doi.org/10.21203/rs.3.rs-35941/v1

License: (c) (i) This work is licensed under a Creative Commons Attribution 4.0 International License. Read Full License 


\section{Abstract}

Background: Heavy metals are toxic elements and can cause serious complications for human health. The aim of the study was to biological monitoring of heavy metals in blood of Kerman residents and its effective parameters.

Methods: This research is a cross-sectional descriptive study with the aim of bio monitoring of heavy metals found in blood of residents in Kerman. Sampling was conducted by random sampling at 8 sites on a total of 80 people (10 per site). The samples were examined by acid digestion using ICPOES to measure the heavy metals.

Results: The results of the present study confirmed a concentration of toxic heavy metals in the blood of residents of Kerman. The maximum concentration of heavy metals were observed in the blood of the residents of Moshtagh and Azadi districts, which were the heavy-traffic areas of the city. A statistically significant relationship was seen between the concentration of some of the above elements and occupation, education and smoking. Statistical tests showed a significant relationship between lead concentration and age.

Conclusions: The results suggested that exposure to lead elements can cause some degrees of depression in humans. The presence of toxic heavy metals in the blood of residents can affect their health and also cause some complications.

\section{Introduction}

Aerodynamic particles with diameter smaller than $2.5 \mu \mathrm{m}$ are considered as one of the most important air contaminants for human health [1, 2]. Dust is considered as a primary source of air contamination in urban environment. Dust particles contain a complex mixture of heavy metals, microorganisms, and numerous carcinogens. The source, composition and concentration of the components of these particles are different [3]. Toxic heavy metals include cadmium, lead, mercury, chromium and arsenic [4]. The chemical elements found in dust enter the blood circulation shortly after skin, digestive and respiratory contacts in human and reach most organs of the body [5].

Heavy metals enter urban dust because of human activities such as transport, social activities, and industrial productions. Dust contamination with heavy metals in urban environments threatens the health of residents [6]. In general, high concentration of heavy metals in the environment can cause health risks such as nervous system disorders, blood, cardiovascular system, kidney, and reproductive system. Its other effects are intelligence decline, attention deficit, and behavioral disorders [7]. In recent years, there is growing concern about the potential exposure to dust containing toxic metals in human. Some metals, such as copper and zinc are harmless in small contents, but some, such as lead, arsenic, mercury, and cadmium are toxic even at very low concentrations, and cause many diseases and cancers [8].

Cadmium and lead are naturally found in soil, and therefore, they can be transferred to air as dust by wind [9]. Dust found in the air, sits easily on the skin and causes heavy metals to enter the body through contact or digestion, or they enter the body directly through the respiratory tract, and finally all of them enter the blood circulation and can affect all organs of the body [10]. Traffic is a potential source of cadmium and lead as a result of combustion of fuel and braking, depreciation of tires, and other components in the air [11, 12].

The results of a study that was conducted to measure heavy metal contamination in the air of two major cities in an eastern province of Saudi Arabia by Sharkawy et al. showed that the concentration of metals in street dust was much higher than the environmental dust. This shows the great contribution of motor vehicles to environmental contamination with metals [13]. Allen et al. (2001) said that the distribution of metals in atmospheric aerosols in the UK has entered atmosphere through a combination of processes including human activities and transport [14]. The results of a study by Wahlin et al. in 2006 show that heavy metals are often associated with high traffic congestion [15].

The potential respiratory and neurological risks of exposure to metals found in the air in Kagiso, South Africa in 2015 was evaluated by Oosthuizen et al. [16]. A study that was carried out by Zheng et al. (2015) on the contamination characteristics and health risk assessment of heavy metals in the air collected from bus stations in Beijing showed that both carcinogenic and non-carcinogenic risk of the selected metals such as cadmium, chromium and lead are in safe range [17].

Measurement of heavy metal contamination level and estimate of health risk of their exposure for humans was conducted by Shabaj et al. in Jeddah, Saudi Arabia using the risk assessment model provided by the US Environmental Protection Agency (USEPA). The results showed that children and adults were at low non-carcinogenic risk. Moreover, the most considerable pathway of exposure has been reported to be the absorption through the skin [18]. The health risk of exposure to toxic heavy metals in dust found in the air of Hamadan city, Iran was evaluated by Sobhan Ardakani (2018). The results showed that the non-carcinogenic risk of chromium for both children and adults was in safe range, and the carcinogenic risk of chromium was below one and acceptable for residents [10]. The results of a study by Ghadimi et al. (2013) on 29 dust samples in city of Arak, Iran, confirmed the large amounts of heavy metals in urban dust [19].

The city of Kerman is located in the semi-arid regions and a decrease in annual rainfall has resulted in decreased vegetation. These factors have increased the amount of dust in the air. Thus, today, the incidence of dust and storms containing dust is increased and is one of the serious environmental issues of Kerman [20]. Consequently, the present research aimed to evaluate the health risk of exposure to heavy metals found in dust in the air of the studied area.

Loading [MathJax]/jax/output/CommonHTML/fonts/TeX/fontdata.js 


\section{Methods And Materials}

\section{Study design}

This research is a descriptive cross-sectional study and is conducted based on collecting dust samples from air of the city of Kerman in certain locations and measuring the concentration of their toxic heavy metals. The carcinogenic and non-carcinogenic risk of their exposure was also evaluated.

\section{Study area}

The city of Kerman is the capital of Kerman province in southeastern Iran and is located on a wide plain in a semi-arid area (Fig. 1). This city is located at latitude of 30.3 and longitude of 57.1 . The elevation above sea level of this city is $1756 \mathrm{~m}$. The area of the city of Kerman is $45401 \mathrm{~km}^{2}$ and has a population of 634132 people based on Census of 2016 [21].

\section{Sample Size Determination}

Sample size was set at 24 based on the correlation calculated from the pilot study and using the sample size determination formula [22].

\section{Sample locations}

In Fig. 2, the borders of eight dust sampling sites in city of Kerman have been specified. At each location, the sampling was carried out at a radius of $5 \mathrm{~km}$. The names of the sampling locations were Jahad Boulevard, beginning of Kuhpayeh Road, Havaniruz junction, Kowsar Square, Resalat Boulevard, Azadi Square, Moshtagh Square, and Khaju Square.

\section{Sampling}

Dust sampling was performed using Dust Fall Jar method. Dust settling container is an open container that is used for collecting particles of air. In this apparatus, the deposition method is used [23]. In eight locations noted in Map 2, the sampling was conducted 3 times and each time during 30 days. The sampling container was installed $2 \mathrm{~m}$ above the ground and was filled with water by half. The container was covered by net to prevent the birds and other objects from entering. The samples were transferred to the laboratory after collection. The sampling was performed during the first 6 months of 2019.

\section{Sample preparation}

Preparation of air settling particle samples was conducted based on the method used by Shao et al. with slightly modification [6]. The samples were digested with a mixture of $\mathrm{HF}-\mathrm{HNO}_{3}-\mathrm{HClO}_{4}$. The preparation steps were as follows. The collected dust sample was dried by heating and $0.5 \mathrm{~g}$ of the dried dust sample was dissolved in $50 \mathrm{ml}$ of polytetrafluoroethylene in crucible, and then $5 \mathrm{ml}$ of $\mathrm{HF}, 5 \mathrm{ml}^{\circ} \mathrm{HNO}_{3}$, and $3 \mathrm{ml}$ of $\mathrm{HClO}_{4}$ were added. The solution-containing container was heated to reach an almost dry state. Then $3 \mathrm{ml}$ of HF, $3 \mathrm{ml}$ of $\mathrm{HNO}_{3}$, and $1 \mathrm{ml}$ of $\mathrm{HClO}_{4}$ were added and heated to approximately reach the dried state. Afterwards, $5 \mathrm{ml}$ of $1 \mathrm{~mol} / \mathrm{L}$ of $\mathrm{HNO}_{3}$ solution was used as solvent. Finally, the samples were kept in a $25 \mathrm{ml}$ container until analysis.

\section{Sample analysis}

Analysis of elements was performed using Inductively Coupled Plasma Spectroscopy Method (ICP-OES) made in Australia with a detection limit of ppm to $\mathrm{ppb}$. In this method, the wavelength calibration was performed using internal calibration by a mercury vapor lamp [24].

\section{Data Analysis}

Data analysis was performed using SPSS v. 26 and Excel 2019. The central tendency and dispersion indicators were used for data description and the correlation analysis was used for data analysis.

\section{Data interpretation}

In this research, various environmental indicators have been used to determine the level of heavy metal contamination. These indicators are as follows: Index of geoaccumulation (Igeo), Enrichment factor, Pollution load index (PLI), Potential ecological risk, and Health risk assessment.

\section{Index of geoaccumulation (Igeo)}

Igeo is used to assess the metal contamination in settle dust [25]. It is computed using Equation1:

$$
\text { Igeo }=\log _{2}\left(\frac{C n}{1.5 B n}\right) 1
$$


Where $\mathrm{Cn}$ is the measured concentration of the examined metal in the settled dust and $\mathrm{Bn}$ is the geochemical background concentration of the metal. Factor 1.5 was used because of possible variations in background values for a given metal in the environment as well as very small anthropogenic influences. The geoaccumulation index (Igeo) was distinguished into seven classes. Igeo $\leq 0$, class 0 , unpolluted; $0<$ Igeo $\leq 1$, class 1 , from unpolluted to moderately polluted; $1<$ Igeo $\leq 2$, class 2 , moderately polluted; $2<$ Igeo $\leq 3$, class 3 , from moderately to strongly polluted; $3<$ Igeo $\leq 4$, class 4 , strangle polluted; $4<$ Igeo $\leq 5$, class 5 , from strongly to extremely polluted; and Igeo $>5$, class 6 , extremely polluted [26, 27].

\section{Enrichment factor}

The enrichment factor of the metals in settled dust was calculated based on Eq. 2 using iron as a reference element since it is the most naturally abundant element in soil [28].

$$
E F=\frac{\left(\frac{M}{F e}\right) \text { sample }}{\left(\frac{M}{F e}\right) \text { shale }} 2
$$

Where EF is enrichment factor, [M]sample and [Fe] sample are the concentrations of each metal and iron at various location of the dumpsite, while $[\mathrm{M}]$ shale and [Fe] shale are average shale concentrations of each metal and iron. Enrichment factor is an indication of the level of accumulation of the element of interest to the natural background level. Thus, it measures the geochemical trend and can be used in making comparisons between an area and overtime. Five contamination categories are recognized on the basis of enrichment factor [29]. These categories are: Deficiency to minimal enrichment for values below 2, Moderate enrichment for values from 2 to 5 , Significant enrichment for values from 5 to 20 , Very high enrichment for values 20 to 40, Extremely high enrichment for values above 40.

\section{Pollution load index (PLI)}

The pollution load index (PLI) is another simple method to assess the level of pollution, was calculated using Eq. 3. In this study, PLI is determined the method proposed by Saleh et. al. [30].

$$
P L I=\sqrt[n]{C_{F 1} \times C_{F 2} \times \cdots \times C_{F n}}
$$

Where $\mathrm{n}$ is the number of metals studied and CF is the contamination factor calculated based on Eq. 4.

The PLI gives an estimate of the metal contamination status and the necessary action that should be taken. PLI $<1$ denotes perfection; PLI = 1 presents that only baseline levels of pollutants are present, and PLI > 1 would indicate deterioration of site quality.

\section{Potential ecological risk}

Potential ecological risk indicator has been used to evaluate the potential environmental risks of metals in dust. In the present study, equations 4 and 5 were used to calculate the ecological risk of heavy metals. In this study, Potential ecological risk is determined the method proposed by Zhang et. al. [31].

$$
\begin{gathered}
E r^{i}=T_{r}^{i} \times C_{f}^{i} C_{f}^{i}=\frac{C_{i}}{C_{b}} 4 \\
R I=\sum_{i=1}^{m} E r^{i} 5
\end{gathered}
$$

Where, $\mathrm{C}_{\mathrm{f}} \mathrm{i}_{\mathrm{i}}$ Contamination factor of the element, $\mathrm{C}_{\mathrm{i}}$ is Concentration of the element in the soil sample, $\mathrm{C}_{\mathrm{b}}$ is Background concentration of the element reference soil (lead $=25$, Arsenic $=4.52$, cadmium $=0.25$, chromium $=79)$

Where $T_{i}^{r}=$ toxic response factor of a given element (lead $=5$, Arsenic $=10$, cadmium $=30$, chromium $\left.=2\right)$. Eri is the potential ecological risk index of a single element; RI is a comprehensive potential ecological risk index [32].

The following terminology were used for the potential ecological risk index: $\mathrm{Er}^{\mathrm{i}}>40$, low potential ecological risk; $40 \geq \mathrm{Er}^{\mathrm{i}}>80$, moderate potential ecological risk; $80 \geq \mathrm{Er}^{\mathrm{i}}>160$, considerable potential ecological risk; $160 \geq \mathrm{Er}^{\mathrm{i}}>320$, high potential ecological risk; and $\mathrm{Er}^{\mathrm{i}} \leq 320$, very high ecological risk and The following terminology are used for the potential ecological risk index: RI >150, low ecological risk; $150 \geq \mathrm{RI}>300$, moderate ecological risk; $300 \geq \mathrm{RI}>600$, considerable ecological risk; and $\mathrm{RI} \leq 600$, very high ecological risk [29].

\section{Health risk assessment:}

Loading [MathJax]/jax/output/CommonHTML/fonts/TeX/fontdata.js 
Health risk assessment was conducted based on the risk assessment of human exposure to risks introduced by U.S. EPA [33]. It was assumed in the present study that the residents receive heavy metals in the dust mainly through mouth, respiration and skin contact.

In this study, the contaminants / human body weight ( $\mathrm{mg} / \mathrm{kg} \times$ day) was used to represent the exposure to contaminants. Formulas 6 to 8 show the average daily exposure to dust through the mouth, skin contact and inhalation, respectively. Formula 9 is the average daily exposure through inhalation of carcinogenic heavy metals. Similar to other studies, the respiratory exposure is considered in this study to evaluate the carcinogenic risk [6].

The daily average exposure dose through hand-mouth feeding (ADDing):

$$
A D D_{\text {ing }}=C \times \frac{I n g R \times E F \times E D}{B W \times A T} \times 10^{-6} 6
$$

The daily average exposure dose through skin contact (ADDdermal):

$$
A D D_{\text {dermal }}=C \times \frac{S A \times S L \times A B S \times E F \times E D}{B W \times A T} \times 10^{-67}
$$

The daily average exposure dose through inhalation (ADDinh):

$$
A D D_{i n h}=C \times \frac{I n h R \times E F \times E D}{P E F \times B W \times A T} 8
$$

The daily average exposure for life through inhalation of carcinogenic heavy metal (LADDinh):

$$
L A D D_{\text {inh }}=\frac{C \times E F}{P E F \times A D} \times\left(\frac{I n h R_{\text {adult }} \times E D_{\text {adult }}}{B W_{\text {adult }}}+\frac{I n h R_{\text {child }} \times E D_{\text {child }}}{B W_{\text {child }}}\right) 9
$$

Where the ADDing, ADDinh and ADDdermal are the average daily dose ( $\mathrm{mg} \mathrm{kg}^{1}$ day $\left.^{-1}\right)$ exposure to metals through ingestion, inhalation and dermal contact, respectively. LADD is the lifetime average daily dose exposure to metals ( $\mathrm{mg} \mathrm{kg}^{1}$ day-1) for cancer risk, The detailed description of the values of exposure factors for children and adults applied to the above models (Equations 5- 8) are given in Tables 1 and 2 [6].

Table 1

Values of exposure factors for heavy metals doses for children and adults

\begin{tabular}{|llll|}
\hline Parameters/Unit & Description & adult & child \\
\hline $\mathrm{C} / \mathrm{mg} / \mathrm{kg}$ & Concentration of metals in dusts & & 180 \\
\hline $\mathrm{EF} / \mathrm{mg} / \mathrm{day}$ & Exposure frequency & 180 & 6 \\
\hline $\mathrm{ED} / \mathrm{years}$ & Exposure duration & 25 & 15 \\
\hline $\mathrm{BW} / \mathrm{kg}$ & Average body weight & 70 & $\mathrm{ED} \times 365$ (non-carcinogen) \\
\hline $\mathrm{AT} / \mathrm{days}$ & Average time & $\mathrm{ED} \times 365$ (non-carcinogen) & $70 \times 365$ (carcinogen) \\
\hline & & $70 \times 365$ (carcinogen) & 200 \\
\hline $\mathrm{IngR} / \mathrm{mg}^{-1} \mathrm{~d}^{-1}$ & Ingestion rate of dust & 100 & 10 \\
\hline $\mathrm{InhR} / \mathrm{m}^{3} \cdot \mathrm{d}^{-1}$ & Inhalation rate of dust & 20 & 2800 \\
$\mathrm{SA} / \mathrm{cm}^{2}$ & Surface area of skin exposed to dust & 3300 & 0.2 \\
\hline $\mathrm{SL} / \mathrm{mg} \cdot \mathrm{cm}^{-2} \cdot \mathrm{d}^{-1}$ & Skin adherence factor & 0.07 & $1.36 \times 10^{9}$ \\
\hline $\mathrm{PEF} / \mathrm{m}^{3} \cdot \mathrm{kg}^{-1}$ & Particular emission factor & $1.36 \times 10^{9}$ & 0.001 \\
\hline $\mathrm{ABS}$ & Absorption factor (Dermal) & 0.001 & \\
\hline
\end{tabular}


Table 2

RfD and SF values of heavy metals

\begin{tabular}{|lllll|}
\hline Element & ing RfD & Dermal RfD & Inhal. RfD & SF Inhal. \\
\hline Pb-non cancer & $3.50 \mathrm{E}-03$ & $5.25 \mathrm{E}-04$ & $3.50 \mathrm{E}-02$ & \\
\hline Pb- cancer & & & & $8.40 \mathrm{E}-01$ \\
\hline Cd-non cancer & $1.00 \mathrm{E}-03$ & $1.00 \mathrm{E}-05$ & 0.001 & \\
\hline Cd-cancer & & & & $6.30 \mathrm{E}+00$ \\
\hline Cr-non cancer & $3.00 \mathrm{E}-03$ & $6.00 \mathrm{E}-05$ & 0.0001 & \\
\hline Cr-cancer & & & & $4.20 \mathrm{E}+01$ \\
\hline As-non cancer & $3.00 \mathrm{E}-04$ & $1.00 \mathrm{E}-05$ & $1.00 \mathrm{E}-03$ & \\
\hline As-cancer & & & & $1.51 \mathrm{E}+01$ \\
\hline
\end{tabular}

In order to evaluate the human health risk of heavy metal exposure from dusts in Kerman, the HQ (Non-carcinogenic hazard quotient), HI (hazards index), and Risk (carcinogenic risk assessment) were applied. The potential risk of carcinogenic and non-carcinogenic hazards for individual metals were calculated using the following equations [12].

$$
\begin{gathered}
H Q=\frac{A D D}{R f D} 10 \\
H I=\sum H Q_{i} 11 \\
R i s k=L A D D \times S F 12 \\
\text { Risk }_{T}=\sum \text { Risk }_{i} 13
\end{gathered}
$$

Where RfD and SF are the values of reference dose $\left(\mathrm{mg} \mathrm{kg}^{1}\right.$ day $\left.{ }^{-1}\right)$ and slope factor. RfD is an estimation of maximum permissible risks to human population through daily exposure. It is recommended that the value of Risk $<10^{-6}$ can be regarded as negligible, whereas Risk $>10^{-4}$ is likely to be harmful to human beings. The acceptable or tolerable risk for regulatory purposes is in the range of $10^{-6} \sim 10^{-4}$. If the value of $\mathrm{HQ} \leq 1$, there is no adverse health effect. The value $H Q>1$, adverse health effects occur. $H I$ value show the sum of the value of the $H Q$ for different substance through different pathways and refers to total risk of non-carcinogenic for a single metal. The value of $\mathrm{HI} \leq 1$ refers that there is no significant non-carcinogenic risk. On the other hand, there is a chance that non-carcinogenic effects may occur when $\mathrm{HI}>1$, and the probability increase with increasing the value of HI $[6,34]$.

\section{Results}

The descriptive results of the heavy metals measurement in the settled dust found in the air of the city of Kerman are shown in Table 3. 
Table 3

Descriptive information of heavy metals in air dust in Kerman

\begin{tabular}{|c|c|c|c|c|c|c|}
\hline \multirow[t]{2}{*}{ Location } & \multirow[t]{2}{*}{ Sample } & \multicolumn{5}{|c|}{ Heavy metal concentration $(\mathrm{mg} / \mathrm{kg})$} \\
\hline & & $\mathrm{Pb}$ & Cd & AS & $\mathrm{Cr}$ & $\mathrm{Fe}$ \\
\hline \multirow[t]{4}{*}{1} & 1 & 67.17 & 0.23 & 8.25 & 36.17 & 13671 \\
\hline & 2 & 63.27 & 0.19 & 6.93 & 31.75 & 11396 \\
\hline & 3 & 60.49 & 0.17 & 6.29 & 28.93 & 12528 \\
\hline & Mean \pm SD & $63.64 \pm 3.35$ & $0.19 \pm .030$ & $7.15 \pm 0.99$ & $32.28 \pm 3.64$ & $12531.66 \pm 1137.50$ \\
\hline \multirow[t]{4}{*}{2} & 1 & 84.23 & 0.44 & 10.61 & 34.12 & 13759 \\
\hline & 2 & 81.31 & 0.41 & 9.7 & 31.72 & 11856 \\
\hline & 3 & 73.62 & 0.32 & 7.67 & 27.73 & 13281 \\
\hline & Mean \pm SD & $79.73 \pm 5.48$ & $0.39 \pm 0.062$ & $9.32 \pm 1.51$ & $30.99 \pm 3.22$ & $12965.34 \pm 989.99$ \\
\hline \multirow[t]{4}{*}{3} & 1 & 82 & 0.29 & 9.43 & 40.75 & 14262 \\
\hline & 2 & 79.17 & 0.23 & 9.15 & 36.18 & 13897 \\
\hline & 3 & 71.29 & 0.19 & 8.75 & 31.57 & 14359 \\
\hline & Mean \pm SD & $78.48 \pm 5.54$ & $0.23 \pm 0.05$ & $9.11 \pm 0.34$ & $36.16 \pm 4.59$ & $14172.67 \pm 243.61$ \\
\hline \multirow[t]{4}{*}{4} & 1 & 89 & 0.37 & 12.5 & 46.91 & 12528 \\
\hline & 2 & 86 & 0.31 & 11.2 & 41.32 & 14379 \\
\hline & 3 & 81 & 0.27 & 9.3 & 37.16 & 13698 \\
\hline & Mean \pm SD & $85.33 \pm 4.04$ & $0.31 \pm 0.05$ & $11 \pm 1.61$ & $41.70 \pm 4.89$ & $13535 \pm 936.20$ \\
\hline \multirow[t]{4}{*}{5} & 1 & 72 & 0.30 & 10.91 & 41.51 & 13693 \\
\hline & 2 & 69 & 0.27 & 9.32 & 37.33 & 12685 \\
\hline & 3 & 57 & 0.21 & 7.53 & 31.57 & 14593 \\
\hline & Mean \pm SD & $66 \pm 4.04$ & $0.26 \pm 0.05$ & $9.25 \pm 1.60$ & $36.80 \pm 4.89$ & $13657 \pm 954.50$ \\
\hline \multirow[t]{4}{*}{6} & 1 & 93 & 0.45 & 14.6 & 52 & 17884 \\
\hline & 2 & 89.12 & 0.39 & 12.8 & 47.6 & 15893 \\
\hline & 3 & 81.23 & 0.36 & 11.2 & 41.8 & 16742 \\
\hline & Mean \pm SD & $87.78 \pm 5.99$ & $0.4 \pm 0.04$ & $12.86 \pm 1.70$ & $47.13 \pm 5.11$ & $16839.67 \pm 999.08$ \\
\hline \multirow[t]{4}{*}{7} & 1 & 47.23 & 0.5 & 12.8 & 42 & 18955 \\
\hline & 2 & 51.01 & 0.7 & 13.6 & 43.7 & 16564 \\
\hline & 3 & 83.37 & 0.43 & 13.53 & 49.13 & 14398 \\
\hline & Mean \pm SD & $60.53 \pm 19.82$ & $0.54 \pm 0.14$ & $13.31 \pm 0.44$ & $44.27 \pm 3.72$ & $16639 \pm 2279.42$ \\
\hline \multirow[t]{4}{*}{8} & 1 & 79 & 0.39 & 11.21 & 42.17 & 15682 \\
\hline & 2 & 71.12 & 0.29 & 9.78 & 39.19 & 13994 \\
\hline & 3 & 63.15 & 0.23 & 7.91 & 34.67 & 14195 \\
\hline & Mean \pm SD & $71.09 \pm 7.92$ & $0.3 \pm 0.08$ & $9.63 \pm 1.65$ & $37.66 \pm 3.77$ & $14623.67 \pm 922.03$ \\
\hline Total & 24 & $73.94 \pm 12.26$ & $0.33 \pm 0.12$ & $10.20 \pm 2.27$ & $38.62 \pm 6.51$ & $14370.50 \pm 1818.47$ \\
\hline standard & & 19 & 0.35 & 7.2 & 54 & 26000 \\
\hline
\end{tabular}


Table 4

Index of geoaccumulation (Igeo) and Enrichment factor (EF) of heavy metals in the settled dust

\begin{tabular}{|llll|}
\hline Metal & Igeo & EF & PLI \\
\hline $\mathrm{Pb}$ & 0.98 & 4.32 & 1.234 \\
$\mathrm{Cd}$ & 3.11 & 1.92 & \\
\cline { 1 - 2 } & -1.62 & 0.71 & \\
\cline { 1 - 2 } & 0.59 & 3.29 & \\
\hline $\mathrm{Fe}$ & -1.13 & 1 & \\
\hline The results obtained from formulas of potential ecological risk are presented in Table 5. \\
\hline
\end{tabular}

Table 5

The potential ecological risk index of heavy metals in the dust

\begin{tabular}{|lll|}
\hline Metal & Cf & $\mathrm{Er}^{\text {' }}$ \\
\hline $\mathrm{Pb}$ & 2.95 & 14.75 \\
\hline $\mathrm{Cd}$ & 1.32 & 39.6 \\
\hline $\mathrm{Cr}$ & 0.49 & 0.98 \\
\hline $\mathrm{As}$ & 2.25 & 22.5 \\
\hline $\mathrm{Fe}$ & 0.68 & - \\
\hline total & & 77.83 \\
\hline
\end{tabular}

The non-carcinogenic risk ( $\mathrm{HQ})$ of all three pathways (ingestion, skin contact and inhalation) for each of the heavy metals for children and adults are presented in Tables 6 and 7.

Table 6

Non-carcinogenic risk of heavy metals in each route of Kerman air dust by adults and children

\begin{tabular}{|c|c|c|c|c|c|c|c|c|c|c|c|c|}
\hline \multirow[t]{3}{*}{ metal } & \multirow{2}{*}{\multicolumn{2}{|c|}{$\begin{array}{l}\text { ADD inh } \\
\text { Non carcinogen }\end{array}$}} & \multirow{2}{*}{\multicolumn{2}{|c|}{$\begin{array}{l}\text { ADDing } \\
\text { Non carcinogen }\end{array}$}} & \multirow{2}{*}{\multicolumn{2}{|c|}{$\begin{array}{l}\text { ADD derm } \\
\text { Non carcinogen }\end{array}$}} & \multirow{2}{*}{\multicolumn{2}{|c|}{$\begin{array}{l}\text { HQ inh } \\
\text { Non carcinogen }\end{array}$}} & \multirow{2}{*}{\multicolumn{2}{|c|}{$\begin{array}{l}\mathrm{HQ} \text { ing } \\
\text { Non carcinogen }\end{array}$}} & \multirow{2}{*}{\multicolumn{2}{|c|}{$\begin{array}{l}\text { HQ derm } \\
\text { Non carcinogen }\end{array}$}} \\
\hline & & & & & & & & & & & & \\
\hline & child & adult & child & adult & child & adult & child & adult & child & adult & child & adult \\
\hline $\mathrm{Pb}$ & $\begin{array}{l}17.8 \mathrm{E}- \\
09\end{array}$ & $\begin{array}{l}7.06 \mathrm{E}- \\
09\end{array}$ & $\begin{array}{l}486.18 \mathrm{E}- \\
06\end{array}$ & $\begin{array}{l}52.91 \mathrm{E}- \\
06\end{array}$ & $\begin{array}{l}1.36 \mathrm{E}- \\
06\end{array}$ & $\begin{array}{l}0.12 \mathrm{E}- \\
06\end{array}$ & $\begin{array}{l}\text { 5/11E- } \\
07\end{array}$ & $\begin{array}{l}2 / 02 \mathrm{E}- \\
07\end{array}$ & $\begin{array}{l}138908 / 8 E- \\
06\end{array}$ & $\begin{array}{l}14883 / 08 E- \\
06\end{array}$ & $\begin{array}{l}0 / 25 \mathrm{E}- \\
02\end{array}$ & 0/02E-02 \\
\hline $\mathrm{Cd}$ & $\begin{array}{l}0.08 \mathrm{E}- \\
09\end{array}$ & $\begin{array}{l}0.03 \mathrm{E}- \\
09\end{array}$ & $2.16 \mathrm{E}-06$ & $\begin{array}{l}0.23 \mathrm{E}- \\
06\end{array}$ & $\begin{array}{l}0.05 \mathrm{E}- \\
07\end{array}$ & $\begin{array}{l}0.05 \mathrm{E}- \\
08\end{array}$ & 79E-09 & 33E-09 & $2.16 \mathrm{E}-06$ & 230E-06 & $\begin{array}{l}500 \mathrm{E}- \\
06\end{array}$ & $50 \mathrm{E}-06$ \\
\hline $\mathrm{Cr}$ & $\begin{array}{l}9.34 \mathrm{E}- \\
09\end{array}$ & $\begin{array}{l}4.002 \mathrm{E}- \\
09\end{array}$ & $\begin{array}{l}253 . \\
94 \mathrm{E}-06\end{array}$ & $\begin{array}{l}27.21 \mathrm{E}- \\
06\end{array}$ & $\begin{array}{l}0.71 \mathrm{E}- \\
06\end{array}$ & $\begin{array}{l}0.06 \mathrm{E}- \\
06\end{array}$ & $\begin{array}{l}93360 \mathrm{E}- \\
09\end{array}$ & $\begin{array}{l}40011 \mathrm{E}- \\
09\end{array}$ & $\begin{array}{l}84646 / 56 \mathrm{E}- \\
06\end{array}$ & $\begin{array}{l}9069 / 26 \mathrm{E}- \\
06\end{array}$ & $\begin{array}{l}1185 \mathrm{E}- \\
06\end{array}$ & $\begin{array}{l}1046 / 66 \mathrm{E}- \\
04\end{array}$ \\
\hline As & $\begin{array}{l}2.46 \mathrm{E}- \\
09\end{array}$ & $\begin{array}{l}1.05 \mathrm{E}- \\
09\end{array}$ & $\begin{array}{l}67.07 E- \\
06\end{array}$ & $\begin{array}{l}7.18 \mathrm{E}- \\
06\end{array}$ & $\begin{array}{l}0.17 \mathrm{E}- \\
06\end{array}$ & $\begin{array}{l}0.01 \mathrm{E}- \\
06\end{array}$ & $\begin{array}{l}2 / 46 \mathrm{E}- \\
06\end{array}$ & $\begin{array}{l}1 / 05 \mathrm{E}- \\
06\end{array}$ & 22/35E-02 & 2/39E-02 & $\begin{array}{l}0 / 18 \mathrm{E}- \\
01\end{array}$ & 0/01E-01 \\
\hline $\mathrm{HI}$ & & & & & & & $\begin{array}{l}96.41 \mathrm{E}- \\
06\end{array}$ & $\begin{array}{l}40.25 \mathrm{E}- \\
06\end{array}$ & $\begin{array}{l}223557.52 \mathrm{E}- \\
06\end{array}$ & $\begin{array}{l}24182.34 \mathrm{E}- \\
06\end{array}$ & $\begin{array}{l}1685 \mathrm{E}- \\
06\end{array}$ & $\begin{array}{l}1096.66 \mathrm{E}- \\
06\end{array}$ \\
\hline
\end{tabular}

Table 7

Risk of carcinogenicity of heavy metals in each route of Kerman air dust by adults and children

\begin{tabular}{|ll|}
\hline metal & LADD-carcinogen \\
\hline $\mathrm{Pb}$ & $4.26 \mathrm{E}-09$ \\
$\mathrm{Cd}$ & $0.02 \mathrm{E}-09$ \\
$\mathrm{Cr}$ & $0.59 \mathrm{E}-09$ \\
\hline $\mathrm{As}$ & $2.23 \mathrm{E}-09$ \\
\hline
\end{tabular}




\section{Discussion}

The descriptive results of the heavy metals measurement in the settled dust found in the air of the city of Kerman are shown in Table 3.

The results show that the highest concentration of lead is at Azadi Square (district 6) and the highest concentration of cadmium, arsenic and chromium is at Moshtagh Square (district 7). The lowest concentration is at Moshtagh Square (district 7) for cadmium and arsenic, at Khaju Square (district 1) of lead, and for chromium at beginning of Kuhpayeh Road (district 2). The standards of heavy metals found in dust presented by U.S. Environmental Protection Agency (U.S.EPA) are shown in Table 3 [35]. According to this table, the arsenic and lead levels are above the permissible limit and the levels of cadmium, chromium and iron are below the permissible limit.

Districts 6 and 7 are among the crowd areas of the city. District 6 was related to the Azadi Square area. Due to the heavy traffic, the dust in the air in this part of the city has the highest concentration of lead. District 7 was related to the Moshtagh Square area. The high concentrations of metals such as cadmium, arsenic and chromium in this area can be associated with small industrial workshops and heavy traffic of vehicles. To determine the relationship between vehicle traffic and heavy metals in dust, some studies are performed by Adedeji (2013) in Nigeria [36], Zhang (2012) in Tibet [37], and Wang (2016) in China [38]. The results of the above studies showed that with an increase in vehicle traffic, the heavy metals in the dust are increased.

\section{Index of geoaccumulation (Igeo), Enrichment factor, Pollution load index (PLI)}

The results of the Igeo, EF and PLI formulas are presented in Table 4. According to Table 4, it was found that average level of measured EF was reduced as $\mathrm{Cr}<\mathrm{Fe}<\mathrm{Cd}<\mathrm{As}<\mathrm{Pb}$. In other words, it can be said that the highest dust enrichment with metals based on $\mathrm{EF}$ index is related to lead and the lowest is related to chromium. The average level of Igeo also had a downward trend: $\mathrm{Cr}<\mathrm{Fe}<\mathrm{Cd}<\mathrm{As}<\mathrm{Pb}$, such that the Igeo index also showed that the highest and lowest levels of dust enrichment with metals are related to lead and chromium, respectively. The index values of Igeo were negative for cadmium, chromium and iron, which represent no environmental contamination with these three elements, whereas lead and arsenic elements have no contamination to average contamination. The PLI value was above 1, representing contamination with dust elements in the air of Kerman city.

According to the PLI index, the dust in the air of this city is contaminated. This is also in agreement with the results of the study by Mmolawa et al. [39]. In the present study, the highest amount of dust enrichment with metals is related to lead. This element is an unnecessary metal for the human body and its excessive absorption can cause damages to the nervous, circulatory, enzymatic, skeletal, endocrine, and immune systems [40-42]. The results of a similar study by Addo et al. to investigate the heavy metal contamination in Ghana showed that the highest amount of enrichment was related to lead with moderate contamination. In thementioned study, the PLI index was also higher than 1 that represents contamination with dust elements in the air of that city [43]. The results of another study in Nigeria by Ihedioha et al. showed that the PLI index is smaller than 1 that indicates no contamination with metals found in dust in the air. Although this waste was highly enriched and is heavily contaminated with cadmium, the contamination had not reached to the point that requires an immediate intervention to alleviate contamination [27].

\section{Potential ecological risk}

The results obtained from formulas of potential ecological risk are presented in Table 5. The results show that the potential ecological risk is low for all the measured metals given the RI value (total ecological risk of elements) that was equal to 77.83 , and therefore is low. In the present study, the total ecological risk of the elements was low. This is consistent with results of the study by Xiong et al. in China, year 2017 [44]. A similar study was conducted by Boban et al. to evaluate the ecological risk of heavy metal contamination in Montenegro. The results showed that the highest ecological risk was related to cadmium and the average ecological risk of all studied elements was low [45]. The results of another study in Ghana by Nkansah showed that the potential ecological risk of elements was high, and the difference in the results compared to the present study is due to the large amount of contamination with arsenic in that country [46].

\section{Carcinogenic and non-carcinogenic risk assessment}

The human health risk assessment is caused by the exposure to heavy metals found in dust samples in the air. The non-carcinogenic risk (HQ) of all three pathways (ingestion, skin contact and inhalation) for each of the heavy metals for children and adults are presented in Tables 6 and 7 . According to the results shown in Table 6 , the HI value was 0.45 . Since it is below 1 , the non-carcinogenic risk of the toxic heavy metals found in dust in the air is low or insignificant. Given that the Risk ${ }_{T}$ value is calculated equal to $106.14 \times 10^{-9}$, it was found that the heavy metals in the air have no carcinogenic risk.

According to the carcinogenic and non-carcinogenic risk assessment of the present study, the highest HQ in both age groups for all heavy metals was higher through ingestion than skin absorption and respiration, and this is in agreement with the results of the study by Li et al., and We et al. It is said in the studies that the level of $\mathrm{HQ}$ in the ingestion and respiration pathways in children is higher than the adults, and it is reported to be more for adults than children in the skin absorption pathway $[47,48]$. In other studies, such as Tianjie et al. in China, the non-carcinogenic risk of exposure to lead and cadmium in the air has been reported to be high for both adults and children [6].

\section{Conclusion}

Loading [MathJax]/jax/output/CommonHTML/fonts/TeX/fontdata.js 
Given that the city of Kerman is located in a semi-arid area, its residents are daily exposed to dust. Dust-containing storms sometimes exacerbate this matter. The results of the present study confirmed a concentration of toxic heavy metals such as lead, cadmium, arsenic and chromium in the dust found in the air of Kerman. Due to the accumulative nature of these elements in nature, the presence of these toxic elements in the dust found in the air and its respiration can cause health-related complications in the residents and increase the ecological risk. According to the calculated concentration of elements and a comparison with standards, it can be concluded that the levels of cadmium, chromium and iron are below the permissible limit and has no a serious risk for health, and the levels of arsenic and lead are above the permissible limit and can threaten the health of residents, especially children.

\section{Abbreviations}

USEPA

United States Environmental Protection Agency

ICP-OES

Inductively Coupled Plasma Spectroscopy Method

Igeo

Index of geoaccumulation,

PLI

Pollution load index

ADDing

Average daily dose $\left(\mathrm{mg} \mathrm{kg}^{1}\right.$ day $\left.^{-1}\right)$ exposure to metals through ingestion

ADDinh

Average daily dose $\left(\mathrm{mg} \mathrm{kg}^{1} \mathrm{day}^{-1}\right)$ exposure to metals through inhalation

ADDdermal

Average daily dose $\left(\mathrm{mg} \mathrm{kg}^{1}\right.$ day $\left.^{-1}\right)$ exposure to metals through dermal contact

HQ

Non-carcinogenic hazard quotient

$\mathrm{HI}$

Hazards index

\section{Declarations}

Ethics approval and consent to participate: This research has been registered with code: IR.KMU.REC.1398.292 on 18 September 2019 , in Ethics Committee of Kerman University of Medical Sciences.

Consent to publication: Not applicable.

Availability of data and material: All required data are included in manuscript.

Funding: The study was supported by Kerman University of Medical Sciences as MSc. thesis.

Authors' contributions: M. Aghasi designed the study and wrote the manuscript. A. Rajabi Analyzed the data, did the experiments and edited the draft. A.A. Roudbari edited the draft and wrote the discussion section and edited the draft.

\section{Acknowledgements:}

The present study was supported by Kerman University of medical sciences as an MSc Thesis. We hereby acknowledge the research deputy of Kerman University of medical sciences, Kerman, Iran.

\section{Competing interests}

The authors declare that they have no conflict of interests.

\section{References}

1. Tan C, et al., Long-term high air pollution exposure induced metabolic adaptations in traffic policemen. Environmental Toxicology and Pharmacology, 2018. (58): p. 156-162.

2. Brunekreef $\mathrm{B}$, et al., Effects of long-term exposure to traffic-related air pollution on respiratory and cardiovascular mortality in the Netherlands: the NLCS-AIR study. Res Rep Health Eff Inst, 2009(139): p. 5-71; discussion 73-89.

3. Bandowe BA, et al. PM 2.5-bound oxygenated PAHs, nitro-PAHs and parent-PAHs from the atmosphere of a Chinese megacity: seasonal variation, sources and cancer risk assessment. Sci Total Environ. 2014;473-474:77-87.

Loading [MathJax]/jax/output/CommonHTML/fonts/TeX/fontdata.js

Page $10 / 13$ 
4. Jose A, Ray JG. Toxic heavy metals in human blood in relation to certain food and environmental samples in Kerala, South India. 2018. 25(8): p. $7946-7953$.

5. Schultze B, et al. Whole blood and serum concentrations of metals in a Swedish population-based sample. Scand J Clin Lab Invest. 2014;74(2):143-8.

6. Shao T, et al. Content of Heavy Metal in the Dust of Leisure Squares and Its Health Risk Assessment-A Case Study of Yanta District in Xi'an. International Journal of Environmental Research Public Health. 2018;15:394.

7. Inyang HI, Bae S. Impacts of dust on environmental systems and human health. J Hazard Mater. 2006;132(1):v-vi.

8. Willers S, Gerhardsson L, Lundh T. Environmental tobacco smoke (ETS) exposure in children with asthma-relation between lead and cadmium, and cotinine concentrations in urine. Respir Med. 2005;99(12):1521-7.

9. lyengar V, Woittiez J. Trace elements in human clinical specimens: evaluation of literature data to identify reference values. Clin Chem. 1988;34(3):474-81.

10. Sobhanardakani S. Human health risk assessment of potentially toxic heavy metals in the atmospheric dust of City of Hamedan, west of Iran. Vol. 25. 2018.

11. Foley T, Betterton EA, Wolf AM. Ambient PM 10 and Metal Concentrations Measured in the Sunnyside Unified School District, Tucson, Arizona. Vol. 43. 2012. 67-76.

12. Lough GC, et al., Emissions of Metals Associated with Motor Vehicle Roadways. Environmental Science \& Technology, 2005. 39(3): p. 826-836.

13. El-Sharkawy MME-SMF. Heavy Metal Contamination of Airborne Dust in the Environment of Two Main Cities in the Eastern Province of Saudi Arabia. 2011.

14. Allen AG, et al. Size distributions of trace metals in atmospheric aerosols in the United Kingdom. Atmos Environ. 2001;35(27):4581-91.

15. Wåhlin P, Berkowicz R, Palmgren F. Characterisation of traffic-generated particulate matter in Copenhagen. Atmos Environ. 2006;40(12):2151-9.

16. Matooane OosthuizenMA,WCY M. and a.P. N., Human health risk assessment of airborne metals to a potentially exposed community: a screening exercise. THE CLEAN AIR JOURNAL, 2015. 25: p. 1.

17. Zheng X, et al. Pollution Characteristics and Health Risk Assessment of Airborne Heavy Metals Collected from Beijing Bus Stations. Int J Environ Res Public Health. 2015;12(8):9658-71.

18. Shabbaj II, et al., Risk Assessment and Implication of Human Exposure to Road Dust Heavy Metals in Jeddah, Saudi Arabia. 2017. 15(1).

19. Ghadimi F. Statistical Analysis of Heavy Metal Contamination in Urban Dusts of Arak, Iran. Vol. 4. 2013.

20. Cordero F, et al. Differentially methylated microRNAs in prediagnostic samples of subjects who developed breast cancer in the European Prospective Investigation into Nutrition and Cancer (EPIC-Italy) cohort. Carcinogenesis. 2015;36(10):1144-53.

21. Statistical Center of Iran. National Portal of Statistics: Population Census and Housing 2016 [cited 201925 January]; Available from: https://www.amar.org.ir.

22. Garcia Asuero A, Sayago A, González G. The Correlation Coefficient: An Overview. Critical Reviews in Analytical Chemistry - CRIT REV ANAL CHEM, 2006. 36: p. 41-59.

23. MOJA MGKSJ. MEASUREMENT AND CHARACTERIZATION OF DUSTFALL SAMPLES FROM MPUMALANGA PROVINCE, SOUTH AFRICA. WIT Transactions on Ecology and The Environment, 2017. 211: p. 111-120.

24. (NIOSH). T.N.I.f.O.S.a.H., ELEMENTS by ICP (Microwave Digestion) 2014.

25. Chowdhury A, Maiti SK, Assessing the ecological health risk in a conserved mangrove ecosystem due to heavy metal pollution: A case study from Sundarbans Biosphere Reserve, India. Human and Ecological Risk Assessment: An International Journal, 2016. 22(7): p. $1519-1541$.

26. Mohiuddin KM, et al. Geochemical distribution of trace metal pollutants in water and sediments of downstream of an urban river. International Journal of Environmental Science Technology. 2010;7(1):17-28.

27. Ihedioha JN, Ukoha PO, Ekere NR. Ecological and human health risk assessment of heavy metal contamination in soil of a municipal solid waste dump in Uyo, Nigeria. Environ Geochem Health. 2017;39(3):497-515.

28. Uno UU, et al., Comparative Study of Levels of Trace Metals in Airborne Particulates in Some Cities of the Niger Delta Region of Nigeria. Environment and Pollution, 2012. 2.

29. Ihedioha J, Ukoha P, Ekere N, Ecological and human health risk assessment of heavy metal contamination in soil of a municipal solid waste dump in Uyo, Nigeria. Environmental Geochemistry and Health, 2016. 39.

30. Saleh S, Thabit A, Amer, Al-Alawi A-H. Potential ecological risk of heavy metals in surface sediments from the Aden coast, Southern Yemen. 2018.

31. Zhang L, Liu J, In situ relationships between spatial-temporal variations in potential ecological risk indexes for metals and the short-term effects on periphyton in a macrophyte-dominated lake: A comparison of structural and functional metrics. Ecotoxicology (London, England), 2014 . 23.

32. Hamzeh MA, Aftabi A, Mirzaee M. Assessing geochemical influence of traffic and other vehicle-related activities on heavy metal contamination in urban soils of Kerman city, using a GIS-based approach. Environ Geochem Health. 2011;33(6):577-94.

33. EPA, U., Exposure Factors Handbook. 2011: Washington.

Loading [MathJax]/jax/output/CommonHTML/fonts/TeX/fontdata.js 
34. Havens D, et al., Blood Lead Levels and Risk Factors for Lead Exposure in a Pediatric Population in Ho Chi Minh City, Vietnam. Int J Environ Res Public Health, 2018. 15(1).

35. (U.S.EPA) Agency(U.S.EPA). U.S.E.P., ISSUE PAPER ON THE.

36. ENVIRONMENTAL CHEMISTRY.

37. OF METALS. 2004: Washington.

38. Adedeji O, Assessment of traffic related heavy metals pollution of roadside soils in emerging urban centres in ljebu-North area of Ogun State, Nigeria. Assessment of traffic related heavy metals pollution of roadside soils in emerging urban centres in ljebu-North area of Ogun State, Nigeria, 2013. 17: p. 509-514.

39. Zhang F, et al. Influence of traffic activity on heavy metal concentrations of roadside farmland soil in mountainous areas. Int J Environ Res Public Health. 2012;9(5):1715-31.

40. Wang C, et al. Traffic-Related Heavy Metal Contamination in Urban Areas and Correlation with Traffic Activity in China. Transportation Research Record: Journal of the Transportation Research Board. 2016;2571:80-9.

41. Mmolawa K, Likuku S, Gaboutloeloe G. Assessment of heavy metal pollution in soils along major roadside areas in Botswana. Afr. J. Environ. Sci. Technol., 2010. 5.

42. Dahrazma B, et al., ASSESSMENT OF HEAVY METALS CONTAMINATION IN THE SOIL OF AY GHALASI ABANDONED LEAD-ZINC MINE AREA, SOUTHEAST TAKAB. GEOSCIENCES, 2015. 24(94 (ENGINEERING \& ENVIRONMENTAL GEOLOGY)): p. 129-138.

43. Yaylali G. Heavy metal contamination of surface soil around Gebze industrial area, Turkey. Microchem J. 2011;99:82-92.

44. Krishna AK, Govil PK. Assessment of heavy metal contamination in soils around Manali industrial area, Chennai, Southern India. Environ Geol. 2008;54(7):1465-72.

45. Addo A. M., et al., Heavy Metal Concentrations in Road Deposited Dust at Ketu-South District, Ghana. International Journal of Science Technology. 2012;2:28-39.

46. Xiong Q, et al., Concentration Levels, Pollution Characteristics and Potential Ecological Risk of Dust Heavy Metals in the Metropolitan Area of Beijing, China. Int J Environ Res Public Health, 2017. 14(10).

47. Mugoša B, et al. Assessment of Ecological Risk of Heavy Metal Contamination in Coastal Municipalities of Montenegro. International Journal of Environmental Research Public Health. 2016;13:393.

48. Nkansah MA, et al. Assessment of pollution levels, potential ecological risk and human health risk of heavy metals/metalloids in dust around fuel filling stations from the Kumasi Metropolis. Ghana Cogent Environmental Science. 2017;3(1):1412153.

49. Wei $X$, et al. Pollution characteristics and health risk assessment of heavy metals in street dusts from different functional areas in Beijing, China. Ecotoxicol Environ Saf. 2015;112:186-92.

50. Liu X, et al., Human health risk assessment of heavy metals in soil-vegetable system: a multi-medium analysis. Sci Total Environ, 2013. 463-464: p. $530-40$.

\section{Figures}

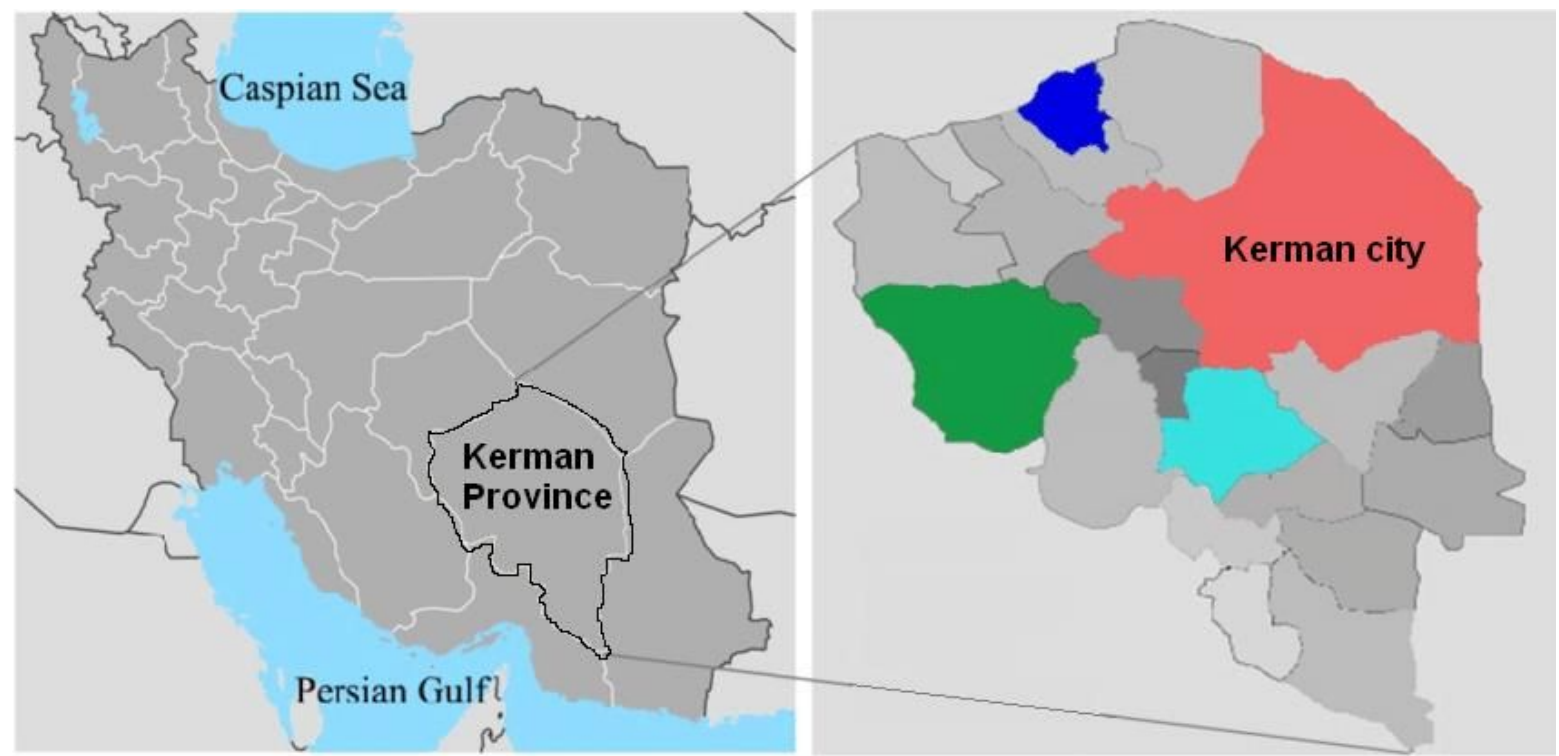

Figure 1

Loading [MathJax]/jax/output/CommonHTML/fonts/TeX/fontdata.js 
Study Area (Kerman City)

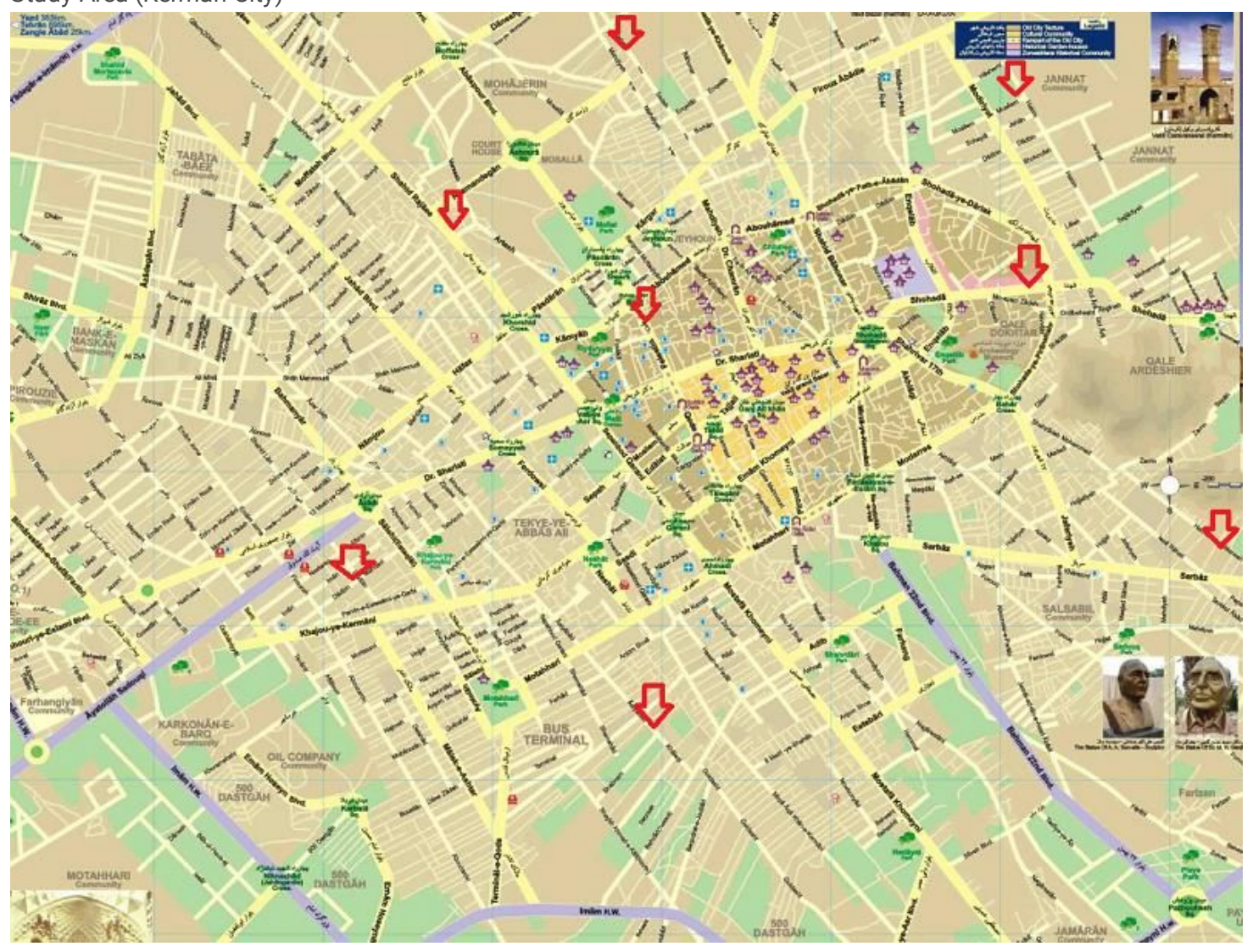

Figure 2

Dust sampling sites in Kerman 